\title{
The Internet of Things (IOT): Impacts on Information Management Field
}

Aumuhaimi Md Yusof, Norhayati Hussin, Kamarul Azwan Azman, Noraizan Amran, Suriana Che Daud, Nor Rashimahwati Tarmuchi

To Link this Article: http://dx.doi.org/10.6007/IJARBSS/v10-i11/8197

DOI:10.6007/IJARBSS/v10-i11/8197

Received: 12 September 2020, Revised: 01 October 2020, Accepted: 10 November 2020

Published Online: 01 December 2020

In-Text Citation: (Yusof, et. al., 2020)

To Cite this Article: Yusof, A. M., Hussin, N., Azman, K. A., Amran, N., Daud, S. C., \& Tarmuchi, N. R. (2020). The Internet of Things (IOT): Impacts on Information Management Field. International Journal of Academic Research in Business and Social Sciences. 10(11), 1208-1216.

Copyright: (c) 2020 The Author(s)

Published by Human Resource Management Academic Research Society (www.hrmars.com)

This article is published under the Creative Commons Attribution (CC BY 4.0) license. Anyone may reproduce, distribute, translate and create derivative works of this article (for both commercial and non-commercial purposes), subject to full attribution to the original publication and authors. The full terms of this license may be seen at: http://creativecommons.org/licences/by/4.0/legalcode

Vol. 10, No. 11, 2020, Pg. 1208 - 1216

Full Terms \& Conditions of access and use can be found at http://hrmars.com/index.php/pages/detail/publication-ethics 


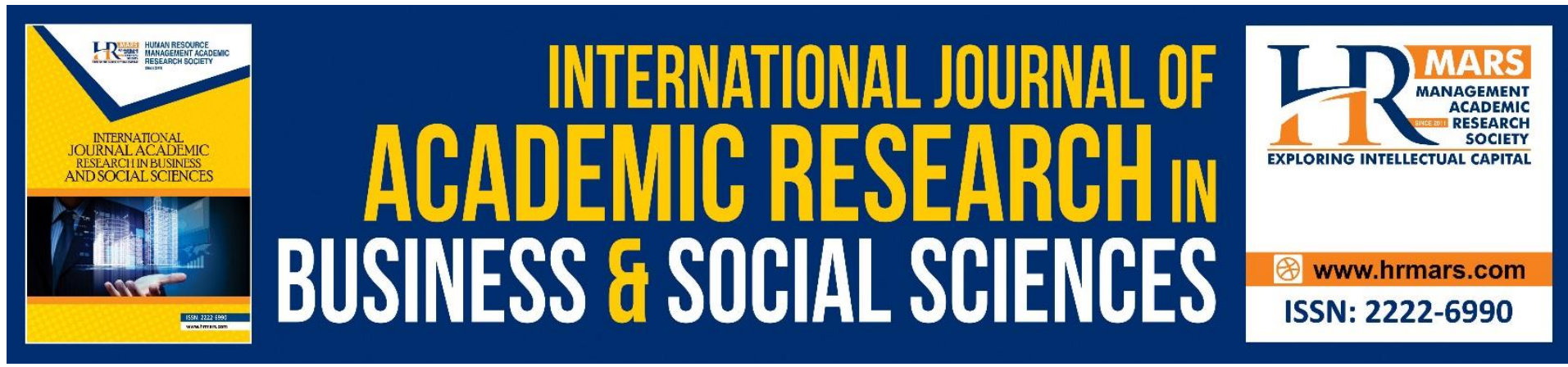

\title{
The Internet of Things (IOT): Impacts on Information Management Field
}

\author{
Aumuhaimi Md Yusof, Norhayati Hussin, Kamarul Azwan \\ Azman, Noraizan Amran, Suriana Che Daud, Nor \\ Rashimahwati Tarmuchi \\ Faculty of Information Management, Universiti Teknologi MARA (UiTM) Selangor, \\ Malaysia
}

\begin{abstract}
The internet connects people through business and social interaction or through business transactions like e-commerce or internet banking. On the other hand, the Internet of Things (IoT) focuses at linking devices or structures with each other through sensors and actuators, to ensure the collection of meaningful information and behaviour can improve human productiveness and output from those systems. It will also lead to the emergence of supplementary or supporting industries and involves many parties that will handle robust information. This paper attempts to discuss the concept of the loT and the impact given to the Information Management (IM) field. In addition to that, this paper will also debate on the IoT's current issues and provides awareness in handling information without deserting the speed of technology adoption.
\end{abstract}

Keyword: Library and Information Management, Internet of Things, IoT, Technology Adoption, Information Issues and Trends

\section{Introduction}

The concept of Industry 4.0 was initially introduced in Germany in 2011 and is known as the Fourth Industrial Revolution. It is very closely linked to the Internet of Things (IoT), CyberPhysical System (CPS), Information and Communications Technology (ICT), Enterprise Architecture (EA), and Enterprise Integration (EI). (Lu, 2017). The loT is mentioned by Marr (2019) is one of Industry 4.0's key components and has been identified by connected devices. It helps internal operations as well as optimizing the equipment through the use of the cloud environment where data is stored. The term "Internet-of-Things" is used as a keyword to cover various aspects of the internet and web expansion into the physical world through the mass deployment of dynamically distributed devices with embedded identification, sensing and/or actuation capabilities. The loT predicts a future in which digital and physical entities can be linked by means of appropriate information and communication technologies to enable a whole new lesson of applications and services. (Miorandi, Sicari, Pellegrini, \& Chlamtac, 2012). 
Postscapes (2019) mentioned that Gartner had released their Top 10 Strategic Technologies list at Gartner's 2011 Symposium, where loT comes in as number 4 on the list. They referred that IoT is a term that explains how the Internet can extend with the application of sensors and information to objects that are connected to the Internet, like consumer products or physical assets. Over the next few years, these developments will reach critical mass and an economic turning point.

Referring to Gartner's point of view, loT has several vital elements which are:

\section{- $\quad$ Embedded Sensors}

Sensors that detect and communicate changes are embedded in a growing number of locations and objects, not just in mobile devices.

\section{- Image Recognition}

Image recognition technologies are designed to identify objects, people, buildings, logos, etc. that are valuable to consumers and businesses. This technology has been moved from primarily industrial applications to large-scale consumer and business applications by smartphones and tablets equipped with a camera.

\section{- $\quad$ Near Field Communication (NFC) Payment}

Through waving their mobile phone in front of a compatible scanner, NFC helps users to make transactions. Once NFC is embedded in a critical mass of payment phones, industries such as public transportation, airlines, retail and healthcare can explore other areas where NFC technology can improve customer service and efficiency.

From all of the loT key elements, they are producing and utilizing information in various kind of field and function. It is clearly known that loT is and will, in future, handling more type of information and we cannot deny that in the evolution of the industry, we will continuously collect, create, receive and capture more data and information. Hence, this will open up many more pros, cons and issues in the field of information and knowledge. It is important for the organization, as well as personal, know how to manage robust information usage in the loT world. In this paper, we will discuss the issues related and also the impact on information management in the next section.

\section{Literature Review}

In this section, we review the literature on the IoT and IM. The literature review provided the theoretical foundation for this writing. It was conducted based on previous scholars' research, further readings on related books and articles as well as information capturing by the recent or current news regarding this topic via electronic pages and online databases.

\section{Concepts of Internet of Things (IoT)}

Morgan (2017) basically describes loT as linking any device with an on and off switch to the Internet. It covers everything from cell phones, coffee makers, washing machines, skylights, mirrors, wearables, and much more. This also applies to machine components, such as an aircraft jet engine or an oil plant box. According to Liu and Sun (2011), the loT-idea is not new, and Gabbai (2015) in his article referring to a conversation with Kevin Ashton claimed that Kevin firstly used the loT term in 1999. The term appears a strange concept during that 
time, and when looked into it further, Kevin said that machines were behaving without sense during the 20th century and only reacted on what was programmed for them. Due to the loT in the 21st century, computers are able to sense things for themselves as, for example, is GPSbased location sensing. In years back, GPS helps people to find a way through the internet, and it is possible in the near future, it will permit such things as self-driving vehicles, reduce traffic and pollution, and allow cities to grow without giving roads as much land.

\section{Concepts of Information}

In our daily work and routine, the word "information" is commonly used. Information is specific and different from data. Information is precise, and information has value in decisionmaking while data does not have. Abumandil and Hassan (2016) state the information have values if it contribute towards the decision making effectiveness to the organization. The information provides clarity and intelligent human response in mind. The data and information are clearly separated in IM. Data is like raw materials, whereas information is equivalent to the goods manufactured after raw materials are processed. The information has some features that improve the company's or individual's representation, update the level of knowledge, have a surprising value, reduce uncertainty, and help in decision- making while the quality of certain information depends on the mixture of these features.

\section{The Importance of Information Management}

The management of information is the compilation and managing information that can come from a number of sources, be collected and transmitted to more than one audience in a variety of formats. Information can come from electronic and physical form. Nevertheless, paper and other digital materials such as audio, personal, business and video content are covered by this definition. In the modern age, digital data is the most commonly mentioned within the information management study. Digital data is the data that show other form of data by using specific machine language system that interpret by various technologies (Tech Review, 2019). The massive of big data has been process which will produce the digital data especially it important to the business organization.

Information management defines how people and organisations use this information. It ensures that the practicalities of how to deal with it must be valued and the ethical considerations of handling confidential and private information at times taken into account. Information management is the responsibility of the organization and should be considered by workers in every position in the company. The organization should have strategy especially the right technology and skill in handling the information. The company should bring variety of technology which integrated among people, process and function in achieve important of business strategy (Kane et al., 2015).

Management of information helps to determine how companies formulate strategies and implement their processes. It is the primary key to business growth. That is why so much effort is poured into designing effective information management systems and trained professionals to help execute them. The strategies management is nothing but planning for predictable and unfeasible contingencies especially for the long term organization sustainability (Tanaji, n.d). There's another side of IM, though and it is agreat responsibility for accessing vast amounts of information. Organizations are constantly under pressure to manage and comply with changing legal regulations with accountability and ethics. People 
and governments, therefore, expect more accountability, it is more necessary than ever for them to handle information about the people that organizations carry.

\section{Current Issues of lot}

The loT can be used from industry to human bodies in almost every aspect of life. Pepper (2014) listed examples of loT devices that, among other elements of today's life, could challenge privacy and security. These were involved:

1. Health and fitness device sensors - such as countertop devices, wearable, intimate and implantable sensors. Various types of personal health tools - from less physically invasive to more invasive - are available to produce and store useful information for frequent users.

2. Automobile sensors (black boxes) - such as Event Data Recorders (EDR), and consumer's automobile sensors. Such sensors can collect an enormous amount of data on vehicle and driver actions.

3. Home and electricity sensors- such as the smart home and the smart grid. Those are types of IoT devices that provide data to homeowners and allow them to remotely control domestic equipment, while simultaneously collecting, transmitting and storing large amounts of information about homes and residents.

4. $\quad$ Employee sensors - These sensors are designed to allow employers to monitor their workers and know what they do and whether they behave according to employment rules or not.

5. Smartphone sensors. One of the most omnipresent new sensor technologies can be considered sensors embedded in smartphones. These sensors can detect physical orientation, track system motion in space and so forth.

Based on the above description, it is clear that the loT devices generates, transmits and stores valuable information on the behaviours, attitudes, characteristics and personalities of consumers and their environment. As much of the information on the internet may be personal information in the loT's environment, it is justified to worry about misuse. In such an intellectual climate, elements of data protection and confidentiality will play a leading role with legal issues.

Dutton (2014) stated in his article that the loT would have privacy concerns in information generation for individuals, while the absence of data often undermines the trust. Balancing such contradictions will be a key aspect of any system or product, just as social networking sites attempt to balance privacy concerns by ensuring that users control their own privacy settings. These issues are closely linked to the uncertainty of ownership and control. This generates a grey area on which the loT data is held in several ways, involving multiple parties, including clients, doctors, hospitals and many more. Copyright arrangements are likely in many cases to transfer ownership of computer-generated data, such as a sensor network, to the system operator. Open systems could threaten ownership and control of these data by the operator, thus enabling more proprietary networks. As a result, data mistreatment and 
other loT- manipulation threats prevention must not be ignored, and there is good reason to have special safety or operating procedures for handling robust data in the loT area.

Moreover, according to Haris @ Harib, Sarijan, \& Hussin (2017), users are not aware of transferring data on the internet and exposing themselves to cyber attackers. This situation might worsen the impact of loT instead of gaining the benefits from it. From this, the priority in giving security to information has to become heavily important. The action to reduce the cons must be taken seriously, and not only the organization should implement policy in securing information and data but awareness to the public about the information management to secure the data transfer must also took into account.

\section{The Impact of Internet of Things on Information Management}

The consequence of loT is producing and utilizing a large amount of big data or information. Brous et al. (2015) specified in their article that loT could have two important advantages for e-commerce. First, making data and information available to the public significantly improves government transparency. Second, enable consumer self-service by using the large volume of information collected by loT and the public's collective knowledge can empower citizens and businesses to take decisions by improving access to information.

Eric and Brett (2017) envisage two broad categories of loT applications which are Information and Analysis and Automation and Control. The ability to make decisions through information and analysis is improved by the obtaining of better and more up-to-date information from networked physical objects, allowing more precise analysis of the current situation concerning tracking, situational awareness and sensor-based decision evaluation. At the same time, the effects of processed data and analysis are used in automation and control for improving efficiency, efficiency and enforcement implementation. Besides, the company has identified six broad applications. They are determined, from behavioural monitoring to enhance environmental and other monitoring sensitivities; resource exploration policy analysis; process optimization; intelligent resource-consumer control-related metering and even complex independent systems in making an autopilot vehicle.

Managing big data produced by the loT is a challenging task. We may want to archive or send large files of both structured and unstructured data and documents to ensure that every department of the company is on the understanding. Organizations are using large data systems to handle fast growth in data pools. Proper data management allows a company to quickly find the structured and unstructured data in a controllable way. There will be many benefits if loT implementation is combined with best practice in the management of data. According to Fleisch (2006), he identified seven loT quality drivers that contribute to future commercial benefits which are: -

1. The "simplified manual proximity trigger" increases job satisfaction, encourages customers to self-serve, reduces work costs and improves the quality of data.;

2. The "automatic proximity trigger" decreases fraud-related costs, system error and labour costs, while providing high complexity data to improve process performance.

3. The "automatic sensor trigger" helps improve the quality of service by providing individual and timely process control, enhances system reliability and productivity and provides an additional level of data quality to identify potential areas for further process 
improvement;

4. Automatic product security reduces costs of a fraud-related process failure, reduces process security costs and enhances consumer confidence;

5. Simple and straightforward input from customers improves service quality and performance by helping processes become more reliable, versatile and faster;

6. Extensive user feedback increases trust by ensuring new customer communication, new advertising incentives and additional service revenue; and

7. Mind-changing feedback enables trends to be identified, new product features and new services to be enabled and attractive customer segments to be actively selected.

\section{Conclusion}

Applications of loT are seen in different domains, and this illustrates the value of loT. The fact remains, however, that there are many problems and issues related to the use of IoT, and they cannot be overlooked. In the discussion of issues and impact on IM, within this academic writing and scope, it can summarize that data and information can be easily accessed anywhere in a real-time using the technology provided in this era. This can be happened because of the network devices, and it may be very convenient for those who unable physically present. The communication between electronic devices is also become much more convenient because of the IoT. It does help people in daily task and routine. The easiness on transferring data and information in a connected network can save time and money as well as more efficient in view of information sharing. IoT also enables the automation of everyday tasks without human intervention. The automation helps to boost the quality of services and reduce the level of human error.

However, we also must keep in mind that loT also can increase the risk of data leakage as confidential information might not be safe and can be sniffed by the third party easily. The network security must also in high priority as devices that produce and utilize the data is connected in a network. A single loophole or failure can affect the entire system and cause a major disaster. For the employment view, the need for human labour would drastically decrease with every task being automated. This will have a direct impact on employability, and there will be a noticeable drop in the skilled hiring process.

Agreed with Shahroom \& Hussin, (2018); Panteli et al., (2013), that the most important processes will be replaced by the development of technologies such as big data and Al and to deal with Industry 4.0 transformation challenges, an organisation need to have a successful strategy. We also may not be aware of it, but we are experiencing major technological changes in everyday task and routine. There is no question that our lifestyle is ruled by technology, representing the reliability of a person on technology. We are pushing to adopt the technology quickly, but that cannot be the reason we left the security in information management behind. Both technology and security must be manipulated parallelly to ensure we are heading safely towards the industrial revolution

\section{Acknowledgement}

This article is financially supported by:

1. Faculty of Information Management, UiTM Selangor, Malaysia 


\section{Corresponding Author}

Norhayati Hussin.

Faculty of Information Management, Universiti Teknologi MARA (UiTM) Selangor, Malaysia.

Email: yatihussin@uitm.edu.my

\section{References}

Abumandil, M. S., \& Hassan, S. (2016). Information quality and decision-making effectiveness: A study of banks in Palestine. International Review of Management and Marketing, 6(7S), 127-132.

Chui, M., Löffler, M., \& Roberts, R. (2010) 'The Internet of Things', McKinsey Quarterly, Vol. 2, No. 2010, pp. 1-9.

Dutton, W. H. (2014). Putting things to work: social and policy challenges for the Internet of things. Info, 16(3), 1-21. doi: 10.1108/info-09-2013-0047

Eric, L., \& Brett, M. (2017). Making sense of Internet of Things platforms. Retrieved from https://www.mckinsey.com/business-functions/mckinsey-digital/ourinsights/making-sense-of-nternet-of-things-platforms.

Fleisch, E., Sarma, S., \& Subirana, B. (2006) 'High-Resolution Management', IESE Alumni Magazine, pp. 8-13.

Gabbai, A. (2015). Kevin Ashton Describes "The Internet of Things". Retrieved April 2020, from https://www.smithsonianmag.com/innovation/kevin-ashton-describes-theinternet-of-things-180953749/.

Haris@harib, A. R., Sarijan, S., \& Hussin, N. (2017). Information Security Challenges: A Malaysian Context. International Journal of Academic Research in Business and Social Sciences, 7(9). doi: 10.6007/ijarbss/v7-i9/3335

How important is information management? (n.d.). Retrieved September 2019, from https://www.edology.com/blog/computing-it/how-important-is-informationmanagement/.

How to Manage Big Data More Efficiently. (n.d.). Retrieved April 2020, from: https://datafloq.com/read/how-to-manage-big-data-more-efficiently/5134.

Kane, G. C., Palmer, D., Phillips, A. N., \& Kiron, D. (2015). Is your business ready for a digital future?. MIT Sloan management review, 56(4), 37.

Liu, X., \& Sun, Y. (2011). Information Flow Management of Vendor-Managed Inventory System in Automobile Parts Inbound Logistics Based on Internet of Things. Journal of Software, 6(7). doi: 10.4304/jsw.6.7.1374-1380

Lu, Y. (2017). Industry 4.0: A survey on technologies, applications and open research issues. Journal of Industrial Information Integration, 6, 1-10. doi: 10.1016/j.jii.2017.04.005

Marr, B. (2019). What is Industry 4.0? Here's A Super Easy Explanation for Anyone. Retrieved from https://www.forbes.com/sites/bernardmarr/2018/09/02/what-is-industry-4-0heres- a-super-easy-explanation-for-anyone/\#19ed0c309788.

Miorandi, D., Sicari, S., Pellegrini, F. D., \& Chlamtac, I. (2012). Internet of things: Vision, applications and research challenges. Ad Hoc Networks, 10(7), 1497-1516. doi: 10.1016/j.adhoc.2012.02.016

Morgan, J. (2017). A Simple Explanation Of 'The Internet Of Things'. Retrieved from https://www.forbes.com/sites/jacobmorgan/2014/05/13/simple-explanationinternet-things-that-anyone-can-understand/\#125f5b7a1d09.

Panteli, P., Griva, E., \& Tsakiridou, E. (2013). Multilingualism in the Cypriot Educational 
System: A Record of Primary School Students' Views and Attitudes. Multilingual Academic Journal of Education and Social Sciences, 1(1), 19-38.

Postscapes. (2019). Internet of Things (IOT) History. Retrieved from https://www.postscapes.com/iot-history/.

Pepper, S. R. (2014). Regulation of the Internet of Things: First Steps Toward Managing Discrimination, Privacy, Security, and Concent

Shahroom, A. A., \& Hussin, N. (2018). Industrial Revolution 4.0 and Education. International Journal of Academic Research in Business and Social Sciences, 8(9), 314-319.

Tech Review (2019). Definition's What is a Digital Data? Definition, Features and More. Retrieved April 2020, from:https://www.computertechreviews.com/definition/digital-data/

Tanaji, D. (n.d). What is Strategic Management Process?. Retrieved April 2020, from: http://www.economicsdiscussion.net/strategic-management/what-is-strategicmanagement-process/31761 